\title{
Ethnography and Photography: What Kind of Collaborations for What Kind of Communications?
}

\section{Manéli Farahmand}

\section{(2) OpenEdition}

\section{Journals}

\section{Electronic version}

URL: http://journals.openedition.org/anthrovision/2658

DOI: 10.4000/anthrovision.2658

ISSN: 2198-6754

\section{Publisher}

VANEASA - Visual Anthropology Network of European Association of Social Anthropologists

\section{Electronic reference}

Manéli Farahmand, «Ethnography and Photography: What Kind of Collaborations for What Kind of Communications? ", Anthrovision [Online], 5.2 | 2017, Online since 31 December 2017, connection on 19 April 2019. URL : http://journals.openedition.org/anthrovision/2658 ; DOI : 10.4000/ anthrovision.2658

This text was automatically generated on 19 April 2019

(c) Anthrovision 


\title{
Ethnography and Photography: What Kind of Collaborations for What Kind of Communications?
}

\author{
Manéli Farahmand
}

\section{Introduction ${ }^{1}$}

1 This article aims to describe the history of a collaboration between ethnography and photography in a "neo-ethnic" field in Mexico. More specifically, it describes the different methodological challenges encountered throughout this collaboration and the choices that were made as a result. The collaboration developed as part of a doctoral research project dedicated to the study of identity issues in contexts of renewal or appropriation of Maya traditions. These issues revolve around quests for authenticity, legitimacy and negotiation of (intra)-cultural differences ${ }^{2}$. As a whole, the research aims to show current transformations in the field of Maya ethnicity, ever since contact with globalized New Age spiritualties. As the New Age gradually spread throughout Latin America, there was a reconfiguration of identity movements towards the end of the $20^{\text {th }}$ century. A new phenomenon arose in the public space: the development of movements seeking Indigenousness by drawing on a New Age and holistic culture. These urban movements, essentially Mixed-race but also including Westerners, are characterized by an "idealized reinterpretation of the past" (De La Peña 1999; 2001). This renewed interest in an exoticized Indigenousness was analysed by ethnologists Jacques Galinier and Antoinette Molinié (2006) in terms of neo-Indianism. The subjects photographed during our collaboration fall within this line of reconstituted spiritual and ethnic identities. We wanted to bring a visual touch to the neo-Indian phenomenon in the Yucatán and Chiapas (south-east Mexico). The holistic, neo-Indian scene in these two regions is dominated by women who locate themselves within a dynamic of empowerment. The subjects photographed are mostly Mexican Mixed-race, or Westerners, members of the uppermiddle class, generally over forty years of age and with higher education. We can observe today in these two regions of Mexico the development of a subculture displaying New Age 
sensitivity, a Cultic Milieu in Colin Campbell's terms (1972), with activities centred on the notion of "healing."

The Cultic Milieu of Chiapas

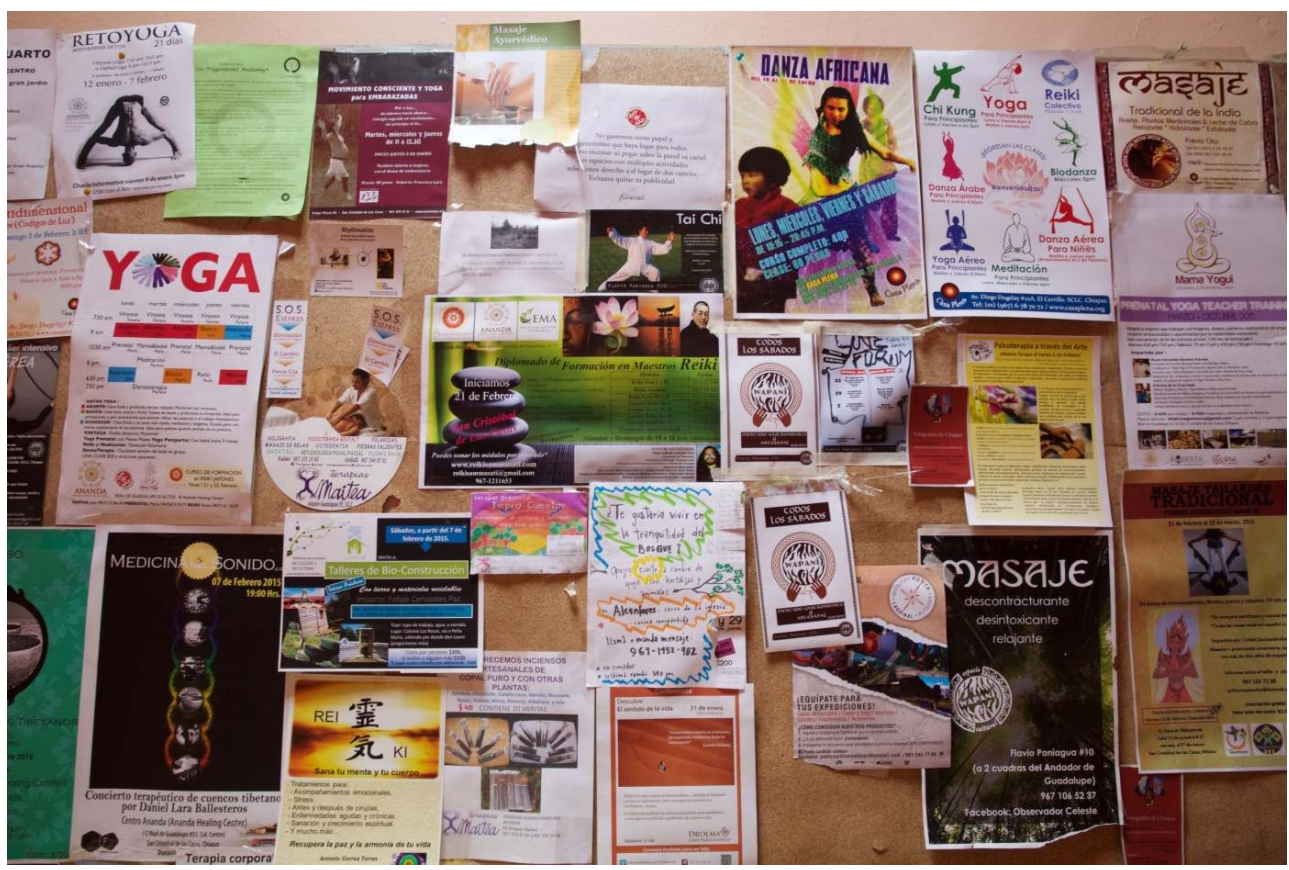

Mexico, San Cristóbal de Las Casas: posters in the streets of San Cristóbal de las Casas, reflecting the dynamism of the local Cultic Milieu. 3 February 2015.

Photo by Laetitia Gessler

2 As we will see, Laetitia Gessler's photographs illustrate this subculture in the Mexican south-east urban spaces. They also feature ritual sequences, portraits, public religious manifestations, and scenes from daily life, syncretic altars, local religious diversity and a wide variety of "neo-Maya"3 objects, with the specific intent of visually documenting this phenomenon.

\section{The Visual Dimension in New Age Spiritualities}

The particular aesthetics of neo-pagan and New Age meetings observed in Switzerland over a six-month period ${ }^{4}$, and the repetition of this aesthetic in Maya New Age ${ }^{5}$ milieu of south-east Mexico between 2012 and 2014, motivated my decision to use the ethnophotographic method, in order to show the important role that images play in these settings. I was facing a wide range of visual information - teaching materials, accessories (stones, jewels, ceremonial objects, cards, incense, liquids), posters, altars, outfits featuring the social class of participants. A kitsch line overflowed with often flashy colours and visually simplified shapes, combining art brut and art therapy. New Agers are by no means marginal. They are professionally integrated, urbanized, from upper-middle classes, with an unlimited access to post-modern technologies. Activities take place in the heart of cities, where top-quality audio-visual accessories are sold, HD imagery accompanies practices, and meditation guides can be downloaded onto iPhone applications. In Mexico, a comparable number of technological and pedagogical visual aids were used in Maya New Age circles. 
The visual dimension of Maya New Age in Playa del Carmen

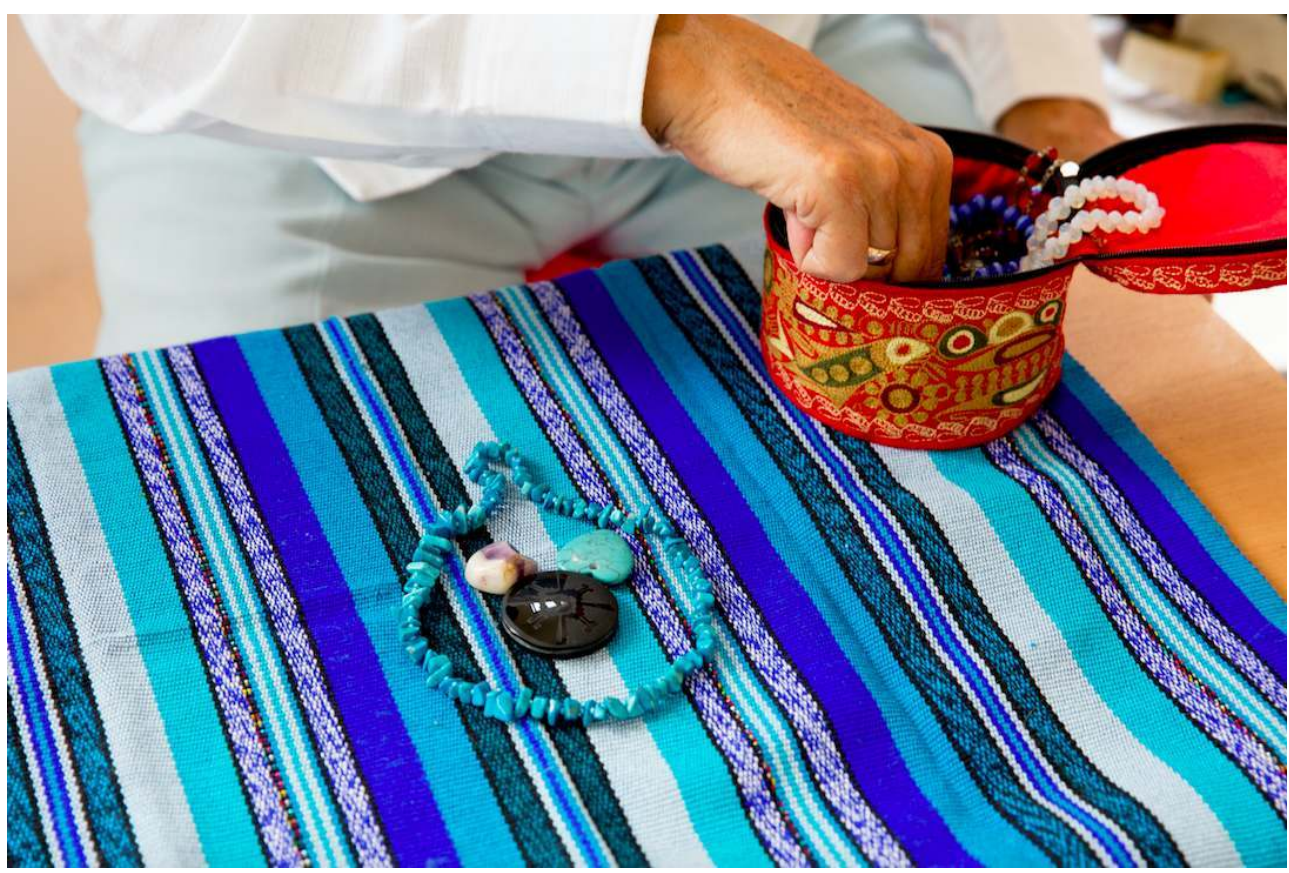

Mexico, Playa del Carmen: "Civilizations in the Age of Aquarius", workshop with Master Domingo Porto Dias, where the signification of many stones was explained. 29 December 2014.

Photo by Laetitia Gessler 
The visual dimension of New Age in Mérida

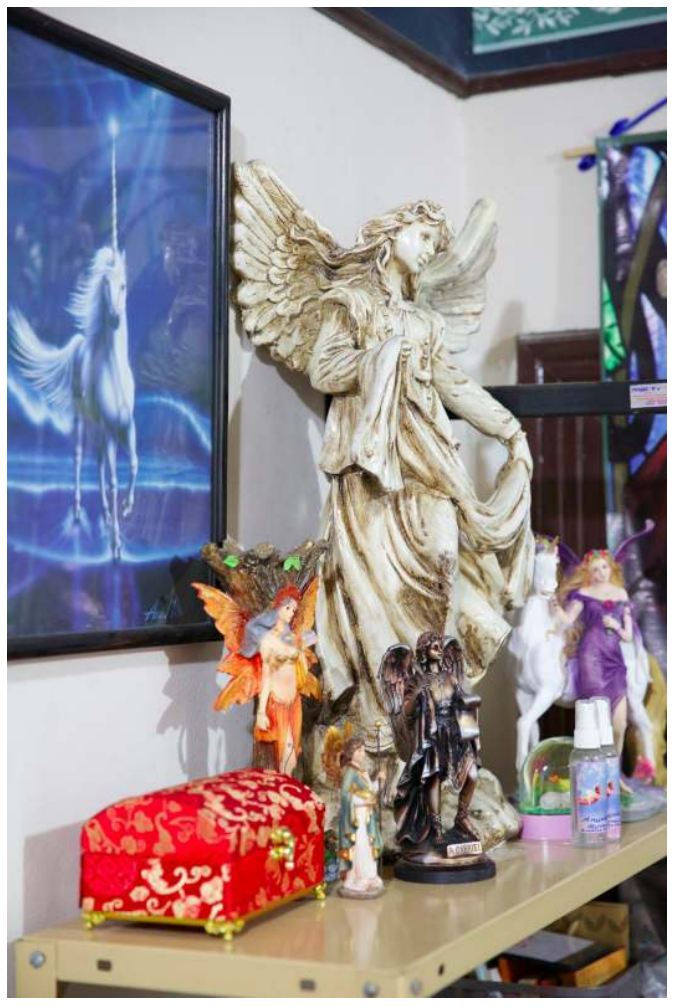

Mexico, Mérida: Decoration at the holistic therapist Ana's place. In the centre, three angelic figures can be seen. On the sides, nymph - or fairy-like figures are seen, including one leaning on a unicorn. 23 December 2014

Photo by Laetitia Gessler 


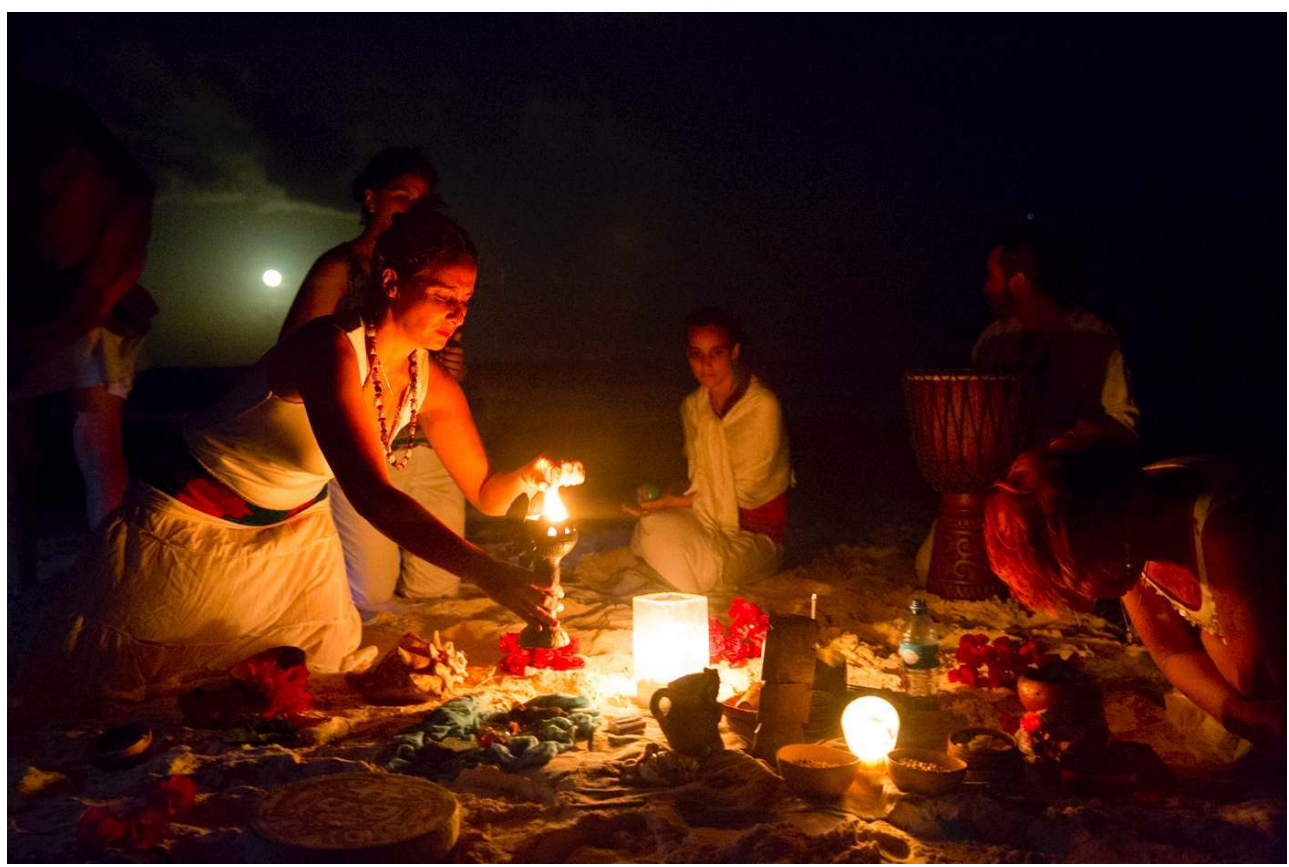

Mexico, Tulum: This rite is dedicated to Ixchel, an archetypal female figure from Maya mythology. At Cristina's place, the figure is associated with "the moon, sexuality, femininity and motherhood". A variety of ritual objects, dresses, colors, and an altar in the centre can be seen. Cristina is lighting the censer to inaugurate the ceremony. 13 January 2015.

Photo by Laetitia Gessler

4 The group known as the Maya Solar Tradition ${ }^{6}$, for example, provides its participants with a "transdimensional Maya meditation" app for cellphones. Moreover, in this group this visual juxtaposition between ethnic and New Age aesthetics is particularly striking. Among the visual representations of the Maya Solar Tradition movement is Kinich Ahau ${ }^{7}$, which is traditionally perceived as "the ancient solar god" (Sotelo Santos 2002: 94) in the Yucatán region, and is represented with an Aryan physique, golden hair, a golden beard, and blue eyes. It is shown wearing a sophisticated, golden outfit. Crowned by a halo, the figure's hands are shown in a mudra, that is, a symbolic gesture taken from Vedic culture. The figure's aura may be considered Christ-like. The central component of Maya Solar Tradition iconography is, therefore, de-ethnicized. It contrasts sharply, on the one hand, with the late classic representation evoking the image of a monstrous divinity and, on the other hand, with the post-classic Yucatecan representation showing a dark-skinned man with Indigenous features seated, seen wearing a plain Maya-style outfit. In Maya New Age settings, images, representation of bodies, altars visual aspect, iconographies are just as much performative aspects fitting into ideals of harmony and social utopias belonging to the "New Age" ideology ${ }^{8}$. Images hold significant social value in those contexts. Anthropologists such as Alejandro Frigerio and Jacques Galinier have shown that the construction of New Age ideology derives from the production of homogenizing and harmonious images, on the basis of a selective process among a variety of cultural elements (Frigerio 2013 and Galinier 2011). While Jacques Galinier focuses on the processes of "symbolic purification" in the "neo-Indian"9 imagery of Mexico, Alejandro Frigerio underlines the power relationships within the construction of New Age systems, specifically through the aestheticization and pacification of borrowed symbols. This 
visual context motivated me to integrate a collaborative fieldwork with the photographer Laetitia Gessler. The collaboration took place in different regions of the Yucatán Peninsula (Mérida, Tulum, Playa del Carmen) and San Cristóbal de las Casas (Chiapas) between December 2014 and February 2015.

\section{Origins of the Collaboration: Photography and Ethnography in a Multi-sited Fieldwork Context}

5 The debate surrounding the transcription of reality has been around since the invention of photography. Even with the desire to be as discreet as possible, positivism has fallen out of fashion in the field of photography: a photographer, by her very presence, inevitably influences the acting and staging of his subjects. Self-representation is transformed when subjects know that they are being observed. While being in a situation similar to a documentary approach, because of the relationship to a historical topic, it was interesting for Laetitia Gessler, the photographer, to encounter the same people in different contexts. On the one hand, these frameworks could be biographical interviews ending in a portrait of the subjects. In these situations, subjects were transformed into models, enabling them to dialogue not only with their social identities but with the image they projected of themselves and, as such, to pose and control their representation. On the other hand, when photographs were taken during ceremonies, another kind of staging was observed, a ritual fiction where the subject continually reproduced gestures, steps and protocols dictated for the occasion. In these ceremonial contexts, individualities were absorbed by collective actions. Subjects were less aware of their image, despite the theatrics and role play, that any ritual would involve. Between the portrait and the ceremonial activity, the performance in the public sphere and the intimate meditation in one's apartment, the body was presented across different registers, according to a polarized dynamic of self-clearing and affirmation, on a background of power issues and social legitimation.

6 The goal of this collaboration initially was to use photography as a tool for comparison of neo-ethnic events between different regional contexts of south-eastern Mexico. 


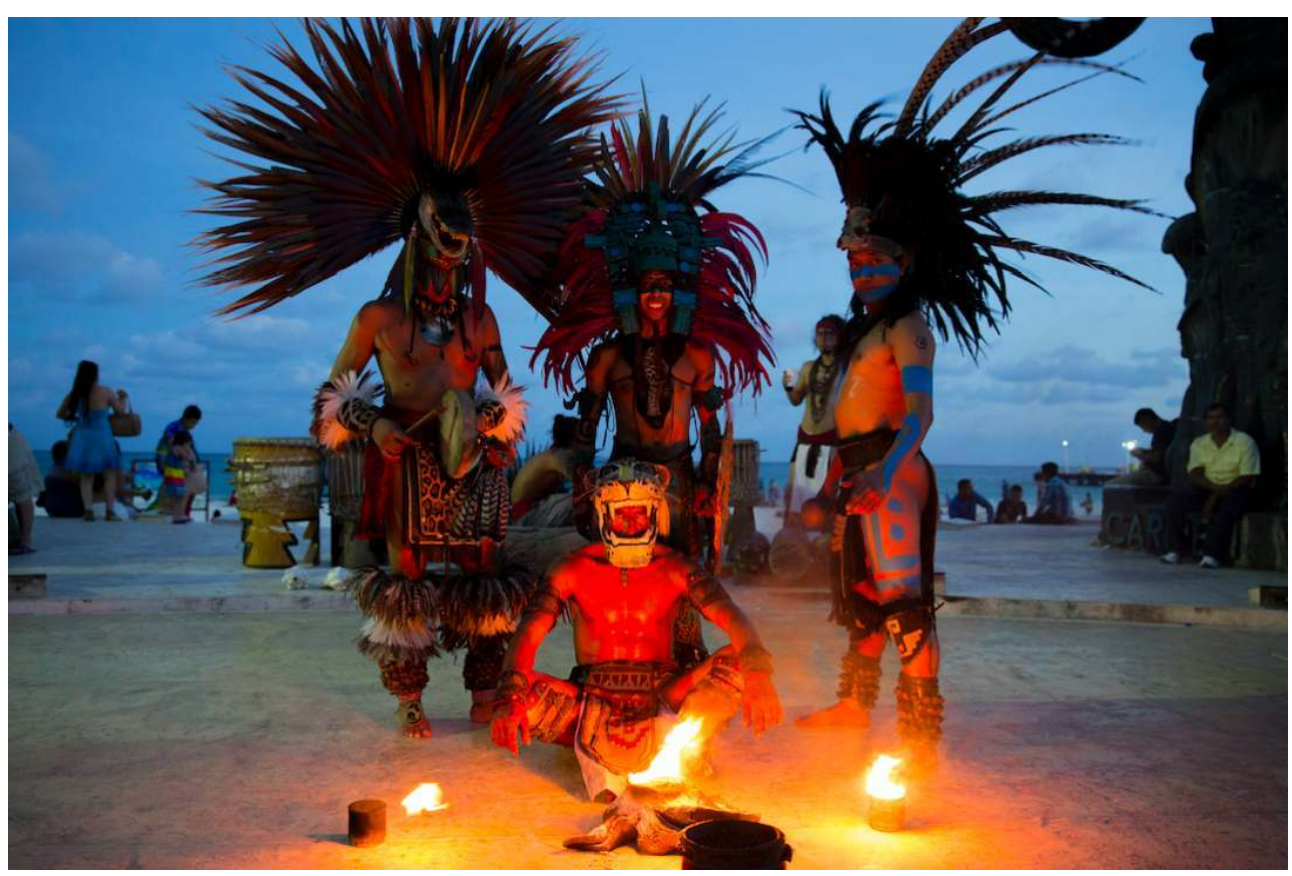

Mexico, Playa del Carmen: Public performance of the pre-Columbian rite to "Huehueteotl" (in Nahuatl language), mythical figure associated with fire for the Mexicas (Aztecs). 31 December 2014.

Photo by Laetitia Gessler

7 My ethnographic inquiry was indeed characterized by a mobility within a social, intranational and transnational field. I moved from one field to another based on events but, especially, based on the movements of actors in a ritual, multi-localized space. This "itinerant ethnographic" model (Argyriadis and De La Torre 2012: 21) led me to different places of neo-Maya production. I thus adopted the logic of a "multi-sited" ethnography in line with the work of George E. Marcus (1995). This approach has also been adopted by De La Torre and Capone, who refer to it as "multi-localized anthropology" (De La Torre 2012; Capone 2004). Multi-sited ethnography essentially consists of following people over time and through space. I adopted this perspective with the goal of tracking the mobility of certain key actors and thereby understanding the new images produced around Mayanity. To that end, my collaboration with Laetitia Gessler in one of the specific fields of this research project made it possible to explore the method of multi-sited ethnophotography.

8 This latter aspect follows Renée De La Torre's approach (2012), an anthology where photography appears as a transversal narrative framework rather than an artistic medium:

In our case, unlike cinema, the sequences are conceived as transversal forms, highlighting not only their sequential character and ritual coherence (vertical frame) but also their cross-overs with horizontal frames (comparison between similar rituals within the same ethnic tradition but practised in different geographic and cultural contexts) [...]. In this sense, photography comes to be seen in this book neither as an art nor for its illustrative potential, but rather for its ability to reveal particular situations, imperceptible facts, captured in the same place, but which, at the same time, connect them to other scenarios and thus enable us to arm a complex discourse of sequences and contrasts among different images 
and in the interweaving of different ritual sequences. A puzzle space that documents multi-localized realities. (De La Torre 2012: 13) ${ }^{10}$

9 As we can see, photography is used here as a tool in the context of an itinerant ethnography on translocalized neo-ethnic rites. This approach was adopted in my research, but unlike this collection, integration of the photographic method was based on a collaboration with a freelance photographer who gave aesthetic value to these images ${ }^{11}$ and both together, we decided to also use her photographs for their illustrative potential. This involved, on the one hand, including the photographer's perspective and, on the other hand, showcasing the artistry of these images in contexts that she was also choosing, that is, within photographic circles.

\section{Photography as a Tool of Ethnographic Observation}

10 As well as using images for comparison between different case studies, the images gradually became valuable illustrative supports and a way of detailing ethnographic observation. From this perspective, they made it possible, on the one hand, to document the visual aspect noted previously and, on the other hand, to reinforce some testimonials and stories. This idea is similarly highlighted by Béatrice Maurines and Angel Sanhuez (2004). In their study, images are produced not only as an illustrative support but also as a way to better understand the field by restoring its initially "invisible" details and therefore apprehending the complexity of the observed social reality:

Within this perspective, the work of the ethnologist must enable the shift from "visible to readable," but it must also be able to dwell on the invisible - by the researcher and also occasionally for the informants - and on that which cannot be expressed without mediation (...). (Maurines and Sanhueza 2004: 33-34) ${ }^{12}$

11 Since the ethnologist's note-taking in the field is often selective, photography becomes a kind of "visual field book," thereby increasing the ethnologist's field of observation and memory. The photographic image from this perspective is considered in terms of its "mediating function" with reference to the work of Sylvaine Conord (2007). As just seen in the quotation, photography for Maurines and Sanhueza is also considered in its tendency to bring more materials, or at least previously inaccessible materials, through a single synchronic observation. Collaboration between photographer and ethnologist thus includes three dimensions: epistemological, methodological, and theoretical. Maurines and Sanhueza's project developed around the benefits of a differentiated "gaze", where each collaborator sees something different in the field due to the discipline-specific competences and techniques (Maurines and Sanhueza 2004: 34). According to the authors, one of the benefits from this co-operation is that in the field, the photographer's role is more accessible and therefore acceptable than the representation of the ethnologist's role. Working together enabled certain kinds of access (Maurines and Sanhueza 2004: 36). Speeds and working methods may also differ but are complementary, as shown in this passage:

In fact, the ethnologist inquiries into the other, into himself, into the coconstruction of the field; assesses the difficulty of access to the 'other...and sometimes grows paralyzed by this position of shifting from engaged to disengaged observer (Devereux 1980). Meanwhile the photographer sizes up the situation and acts. Mediation between his thought and action is much briefer and sometimes more immediately productive. (Maurines and Sanhueza 2004: 36$)^{13}$. 
12 As John Collier and Malcolm Collier have also pointed out in their important work Visual Anthropology. Photography as a Research Method (1986: 16), "photography offers the stranger in the field a means of recording large areas authentically, rapidly, and with great detail, and a means of storing away complex descriptions for future use". Our methodological and epistemological perspective, in collaboration with Laetitia Gessler, fits into this kind of approach, which seeks to enable the use of visual communication media in ethnographic work from the perspective of complementarity. In this perspective, our collaboration had a two-fold objective, as mentioned: to provide more observational data; and to detail the field of ethnographic observation for purposes of illustration and comparative analysis. Conversely, the ethnographic inquiry was used by Laetitia Gessler, the photographer, to complete, textually document, and deepen the meaning of photographic images, thereby enhancing their historical value.

\section{Locating the Photographic Medium in Visual Anthropology}

13 The theoretical debates on the relationship between anthropology and photography, which have taken place over the last thirty years in the field of visual anthropology reflect on the current and historical status of photography in anthropology. A partial overview of a few reflections on this relationship seems useful here. Christopher Pinney explains the relationship of anthropology with photography from a historical perspective. He emphasizes the obvious interest of anthropology - due to its colonial past - in interactions between culture and images, and between images and power:

There are many anthropologies. However, one version of anthropology has closely, and critically, scrutinized its colonial past, and one version of anthropology has subjected itself to ethico-political self-critique more trenchantly, perhaps, than any other practice in social sciences and humanities. Because of this, anthropology (or at least one version of it) occupies a good place - perhaps a uniquely privileged place - from which to consider the relationship between images and culture, and images and power. (Pinney 2011: 11-12).

Nélia Dias also rightly reminds us that we cannot separate historically the development of anthropology from the development of photography (1994). Since the second half of the $19^{\text {th }}$ century, photography has been mobilized by anthropologists according to anthropometric rules (profile photographs with the body measurements of Indigenous people), to study what was called "primitives" from a variety of evolutionary perspectives (Dias 1994: 40). This has been done according to the "colonial aesthetics" (Pinney 2011: 139). On the history of anthropology's relationship with photography and colonialism, Elizabeth Edwards' important work (1992) also stresses the importance of historical relations and contexts. She specifically describes this relationship from the perspective of power, in the following terms:

The power relations of the colonial situation were not only those of overt oppression, but also of insidious, unequal relationships which permeated all facets of cultural confrontation. Indeed, this confrontation included local power relations of the white-settled lands. While this relationship was in many cases tempered at an individual level with a genuine desire for a sympathetic understanding of people in human terms, such intentions were inevitably confronted by the intellectual difficulties of such intentions were inevitably confronted by the intellectual difficulties of such an endeavour, and the unequal relationship was sustained 
through a controlling knowledge which appropriated the 'reality' of other cultures into ordered structure. Photography was in many ways symbolic of this relationship. It represented technological superiority harnessed to the delineation and control of the physical world. (...) (Edwards 1992:6).

These uses were guided by positivist representations of reality, which stipulate that there is some kind of "reality prior to taking any photograph, which could then be faithfully rendered by the camera." In this context, the photograph is seen as a "neutral witness" and an "authentic revealer" (Dias 1994: 44). In these contexts, the background ideology was based on biological determinism:

Culture was seen as biologically determined. Non-European races, who appeared less accomplished technologically were interpreted as representing the childhood of man-kind', a phase through which European man had passed in his prehistoric and proto-historic periods in a linear progression toward 'civilization'. (Edwards 1992:6).

Today anthropological photography has taken the subjectivist turn, and assertions on its role as a substitute for reality and of an objective photographer-observer have given way to a vision of the photographic image as a partial and unique representation of a photographing subject ${ }^{14}$. Sylvaine Conord (2007: 11) emphasizes this idea by indicating that photographic work primarily concerns the representation of otherness, the photographed subject, and the construction of self-image. She also reminds us that since the $1960 \mathrm{~s}$ in France, visual anthropology - or rather cinematographic approaches within visual anthropology - have been recognized, largely thanks to the work of Jean Rouch, but that it is only since the 1990s that photography has been considered a methodological tool in its own right. By contrast, the anthropological use of photography in the United States was already established, as shown, among others, by the ethno-photographic collaboration of Margaret Mead and Gregory Bateson in Balinese character: A photographic analysis (1942) and Howard Becker's famous work on visual sociology, "Exploring society photographically" (1981) (Conord 2007: 11). The special issue of Ethnologie française (2007), dedicated to the status of photography in the field of anthropology, specifically set out to fill these gaps by generating debate around its epistemological foundations, the relationships between photographic image and writing, the issue of new communication media with new technologies, and the selection of snapshots in the field. Photography is seen as a "way of knowing" through its "power of designation" (Conord 2007: 12; Piette 2007). It seeks to restore the place of anthropological photography alongside filmed visual anthropology. The specificity of the photographic medium in relation to other visual tools (e.g., iconography, painting, cinema, drawing) is defined as follows: "Photography is clearly delineated by a formal, subjective framework, constructed by the technical and aesthetic choices of the photographing subject arising from her relations with the world and with the photographed subjects (Conord 2007: 12) ${ }^{15}$." Thus, Conord is against the limited uses of the photographic technique in anthropological contexts for merely illustrative purposes, which specifically overshadow the thematic placement of shooting methods, photographic framing, and other methods mobilized by the photographer. In the context of my research, photography, as mentioned, specifically served as illustrative support and visual reinforcement of the data, thereby bolstering my analysis of the interpretation of the symbolically eclectic dimension for certain ceremonies, altars and even the gender roles. Similar to Conord, in our field, photography also generated bonds of trust with actors in the field and contributed in part to the construction of groups' self- 
image. These photographs were often reused on groups' respective websites and social networks.

On differentiated gender roles during the Maya winter solstice ceremony

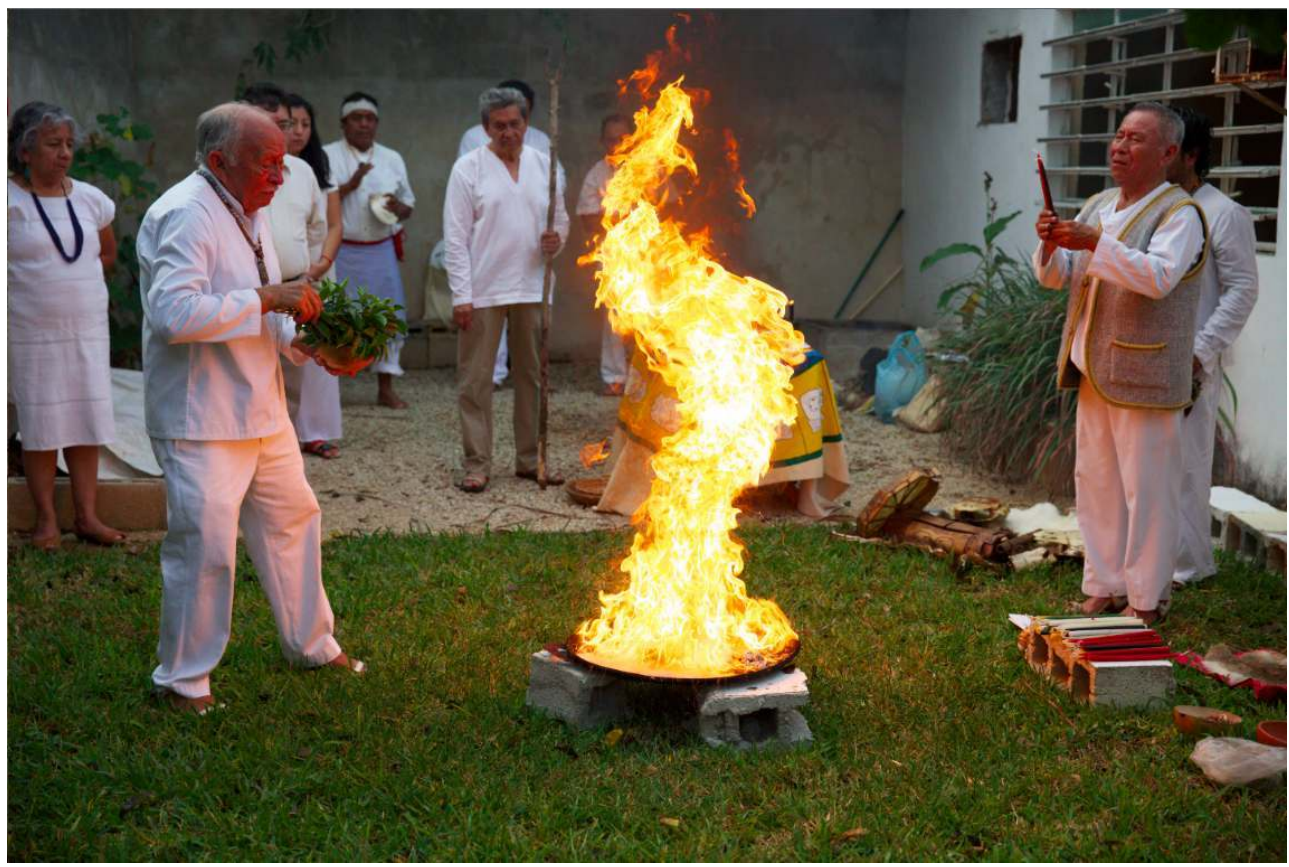

Mexico, Mérida: In the picture, two members of the Council of Maya Elders ${ }^{16}$ "work with the sacred fire". The next day, a participant revealed to me, "In a Maya ceremony, women do internal, passive work because their energy comes from the earth. Men's energy comes from the sun, but one is not worth more than the other (...)". This image shows the active, external role of men with the fire in the foreground, and the passive, internal role of women in the background. 28 January 2015

Photo by Laetitia Gessler 


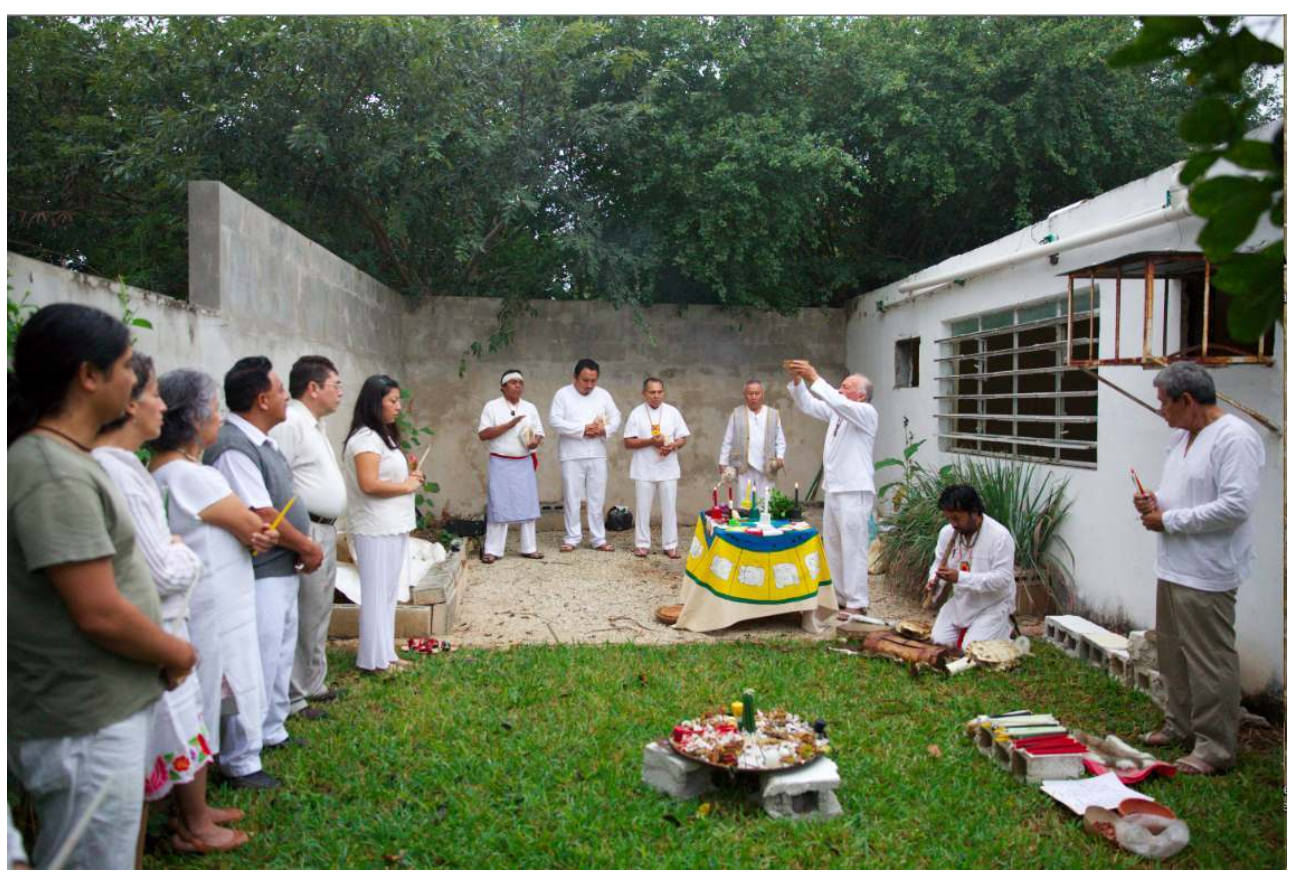

Mexico, Mérida: "Maya Winter solstice ceremony". Participants silently observe one of the members of the Council of Elders dedicating a prayer to water on the Maya altar. The candles are lit one after another in continuity with the "fire element" and are then tossed into the central fire. A majority of men are present at this ceremony. Women have recently joined the Council of Elders. 21 December 2014.

Photo by Laetitia Gessler

\section{The Issue of the Right to One's Image and Facilitating Access to the Field}

Subject to the constraints imposed by the right to the protection of one's image, ethnologists wishing to diffuse field photography's must obtain the authorization of the photographed subjects. Valérie Game's (2007) legal notes on this subject are illuminating. She underlines the importance of written agreements, giving the first and last names of the people photographed and the contexts in which the images will be diffused. Spoken agreements would not be authoritative in case of conflict (Game 2007: 87). Respect for privacy, establishing a relationship of trust, and the right of individuals to their image were all ethical aspects that we considered as part of our project. With the status of the image differing between private space ("absolute protection") and public space ("relative protection") (Game 2007: 87), we also needed to anticipate the issues and consequences surrounding our approach according to photographing both, public and private religious life. Publishing images taken during a ceremony in an apartment did not meet the same conditions as photographing rituals in the public square.

In addition to these issues, there were also questions about the use of images in academic and artistic contexts. We thus developed two kinds of contracts. A first contract was drafted between Laetitia Gessler and myself concerning the mutual use of photographic and ethnographic materials subject to mutual consultation and in keeping with the individual contracts signed by each people photographed. We prepared a second 
document, which outlined the PhD project, the ethno-photographic collaboration, and the final project of showcasing the photographs through publications, exhibits, and the design of a general public book complete with photographs and ethnographic descriptions. In this text, we guaranteed participants' anonymity through the use of pseudonyms and respect for their privacy in the dissemination of images ${ }^{17}$. We also guaranteed that participants would receive their photographs back, professionally retouched, film sequences in which they were involved, as well as a copy of the future publication. The contract included spaces for signatures and the contact information of all parties concerned. This contract of initial trust with the actors made it possible to gain easier access to the field. We were more often invited to take part in rituals or to join groups during activities after the contract had been finalized. The presence of photography in the field served as a sign of credibility and recognition of the ethnographic inquiry.

\section{Methodological Benefits of Collaborating in the Field}

19 In practical terms, while in the field, Laetitia Gessler was responsible for taking the photographs while I looked after the interviews, filming and documentary research. At the same time, during direct observation sessions, we both took on the role of participant-observer. One of the benefits of this collaboration was, as I said previously, that photography helped us integrate in the field. Much like the research of Maurines and Sanhueza, photographic skills were better recognized by people than was the ethnographic position. Photography has historical and empirical value. As Elizabeth Edwards points out, "The undeniable authority of the photograph is grounded in its temporal and physical presence. It was there. The photograph confirms the presence and observation of the photographer and 'truth' his account" (Edward 1992:7).

Moreover, Laetitia's position made it possible, in general, to increase material and symbolic exchanges (giving the photographs away as gifts; voluntary staging in front of the camera). The literature on collaboration between photographer and ethnologist mentions this, as well. The photographer's role is often more explicit in the field, whereas the perception of the ethnologist's activities is more complex to decipher and, consequently, more difficult to accept (Conord 2007). The ethnologist is also less visibly active than the photographer. The gifts of the retouched photographs while in the field gave photography a mediating role in interpersonal relationship ${ }^{18}$ By the same token, giving film sequences to our participants granted us easier access to certain situations based on a reciprocal exchange. Thus, (audio)-visual approaches allowed us to establish relationships of trust in the field.

\section{During the Fieldwork}

21 Laetitia Gessler accompanied me at almost every ceremony. She took pictures while I took notes. She was also present during most of the life-story interviews (in any case, for those participants who had agreed to have their portraits taken). She took portraits before and after each interview. 


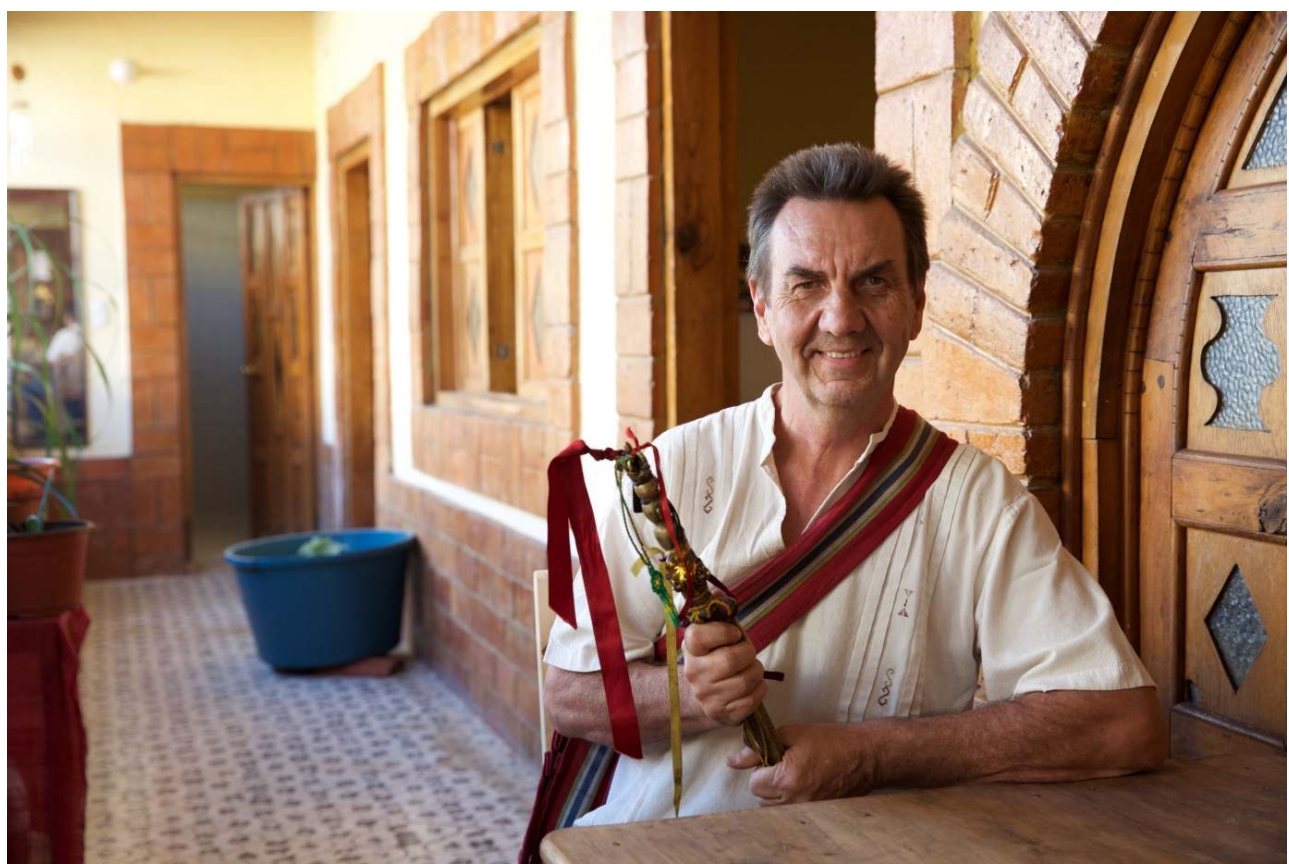

Mexico, San Cristóbal de Las Casas: Ron on the patio of his apartment posing with his "Moses stick" that he himself made during his spiritual encounters. He also works with "Maya spiritualities" from a New Age perspective. 28 January 2015.

Photo by Laetitia Gessler

The narrative interviews sought to understand the social conditions in which participants lived, the kinds of biographical experiences that had influenced their decision to incorporate neo-Maya ways into their lives or perceptions of gender expressed in their biographies. For Laetitia Gessler the interviews added depth to the photographic portraits. When she took the portraits at the end of interviews, the subjects' narratives influenced her photographer's gaze. Photographic portrait and life-story method were seen as complementary. For the sample, we selected key actors in the local networks. They were photographed initially in their ceremonial context, wearing ritual clothing and accessories. 


\section{Ricardo in a ceremonial context}

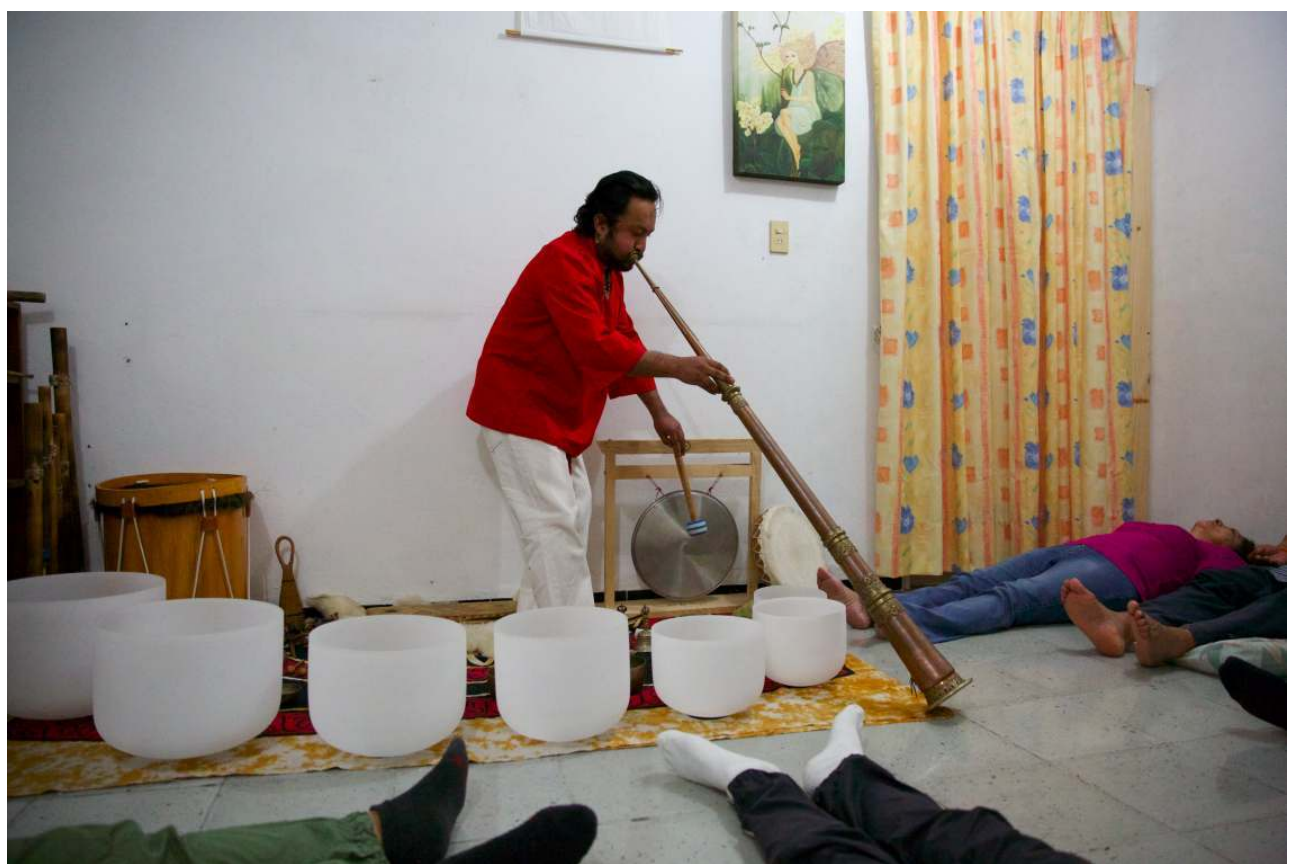

Mexico, Mérida: Ricardo performs a ceremony of "harmonization through sound". There are people lying down and meditating on the sounds, in an apartment on the outskirts of the city. 8 February 2015.

Photo by Laetitia Gessler

Their portraits were then taken later in a situation from their daily life, a cross between public and private spheres. 
On portrait in Mérida

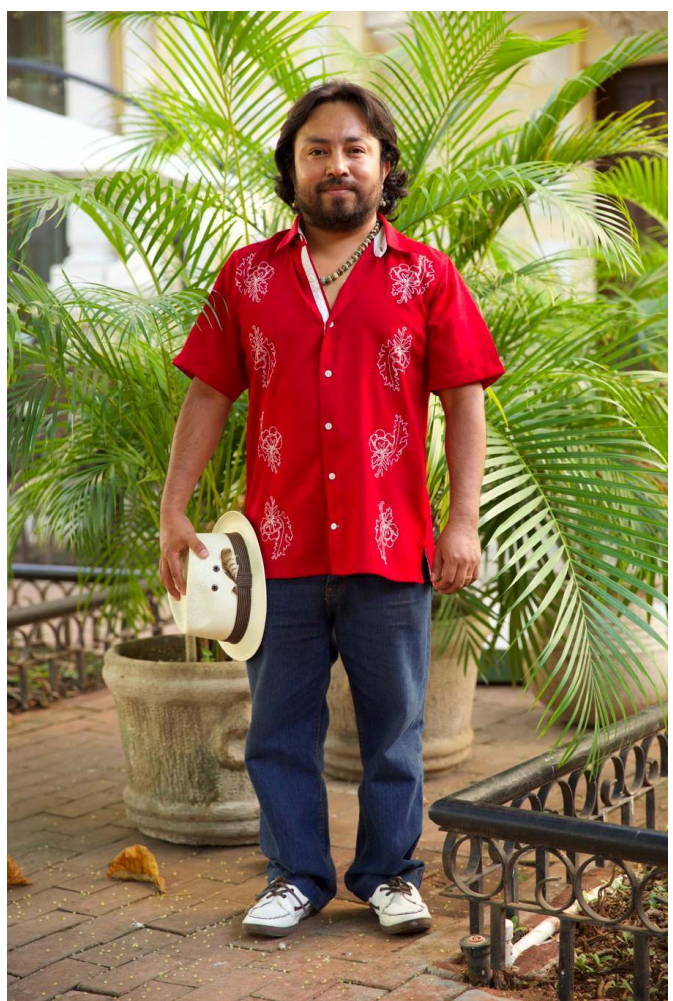

Mexico, Mérida: Ricardo in his everyday attire. 9 February 2015.

Photo by Laetitia Gessler

This approach allowed us to visually capture the contrast between the simplicity of selfpresentation in daily life and the complex performances of the ritual in space and time. This complexity was reinforced by the use of numerous accessories, clothing and symbolic objects.

\section{Classifying and Processing the Photographic Images}

To be able to use Laetitia Gessler's photographs in an illustrative sense and as a tool for comparative analysis (2000 photographs in total), it was necessary to think of a data classification strategy that could reduce the data and their conceptualization. In this case, it involved developing categories based on studying the photographs and establishing analytical relationships among them (Strauss and Corbin, 2004: 29). In this sense, the classification was similar to the coding procedure used in Grounded Theory (Glaser and Strauss, [1967] 2010). For example, we used codes such as "syncretic altar", "contextual scenes", "gender divisions", "ceremonial altar" to classify them. 
"Syncretic Altar"

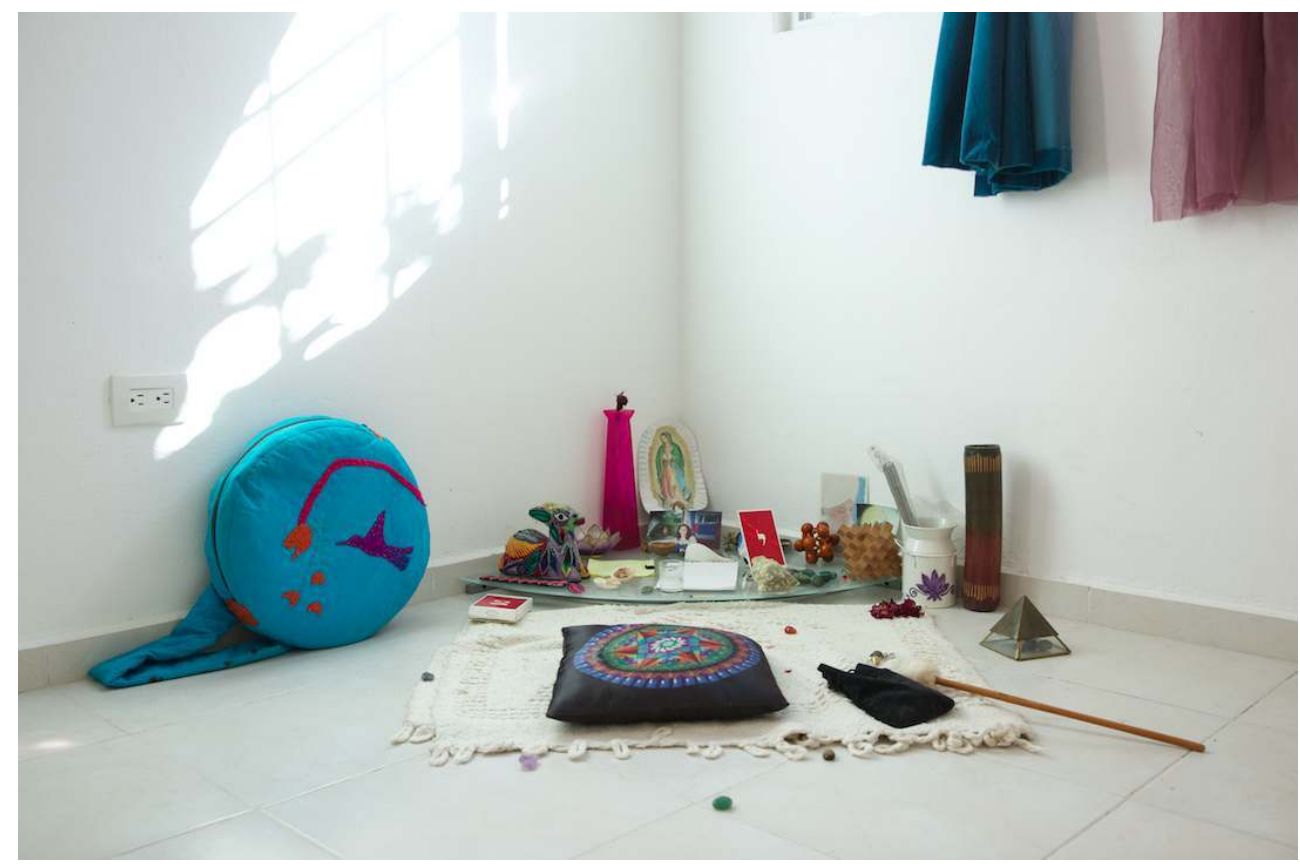

Mexico, Mérida: A therapist's syncretic altar, who combines Otomí and Mexica massages, healing roses, numerology, iridology, and tarot. From left to right on the image: covered shamanic drum, deer of Huichol origin, lotus candle holder, dried rose, icon of the Virgin of Guadalupe, photograph of the therapist, bronze statue of Shiva, bird feathers, wooden geometric statues known as "merkabas" in reference to the Jewish mystic, card with the Hebrew letter Yod, bag of seeds, water gourd, copal incense holder, quartz crystal pyramid, bag of quartz, meditation cushion with star-shaped decoration, pyramid in quartz. 15 January 2015.

Photo by Laetitia Gessler 


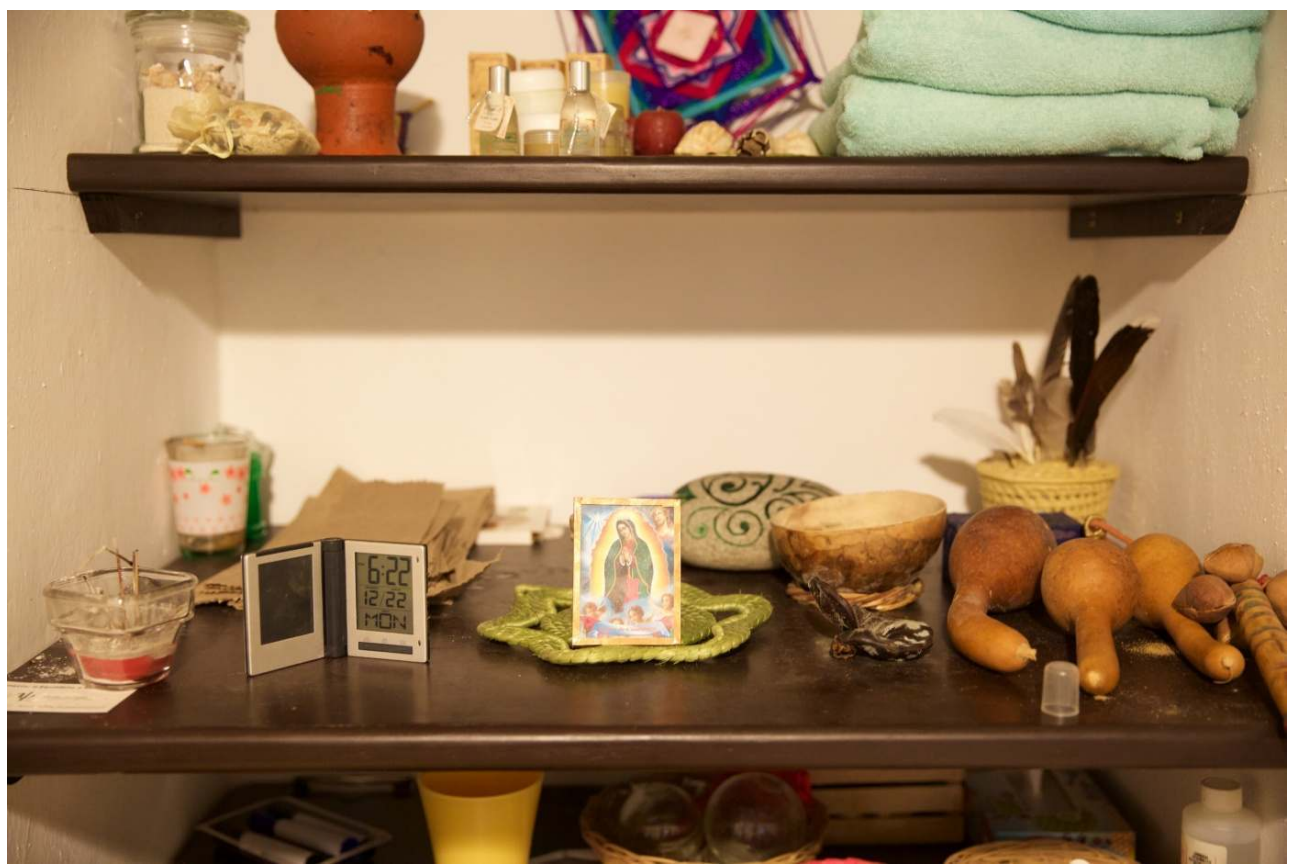

Mexico, Mérida: neo-Maya altar at Maria's place, with the figure of the Virgin of Guadalupe in the centre. We also observe ritual and symbolic objects, such as percussion instruments, feathers, a candle and a censer. 22 December 2014.

Photo by Laetitia Gessler

\section{On contextual scene}

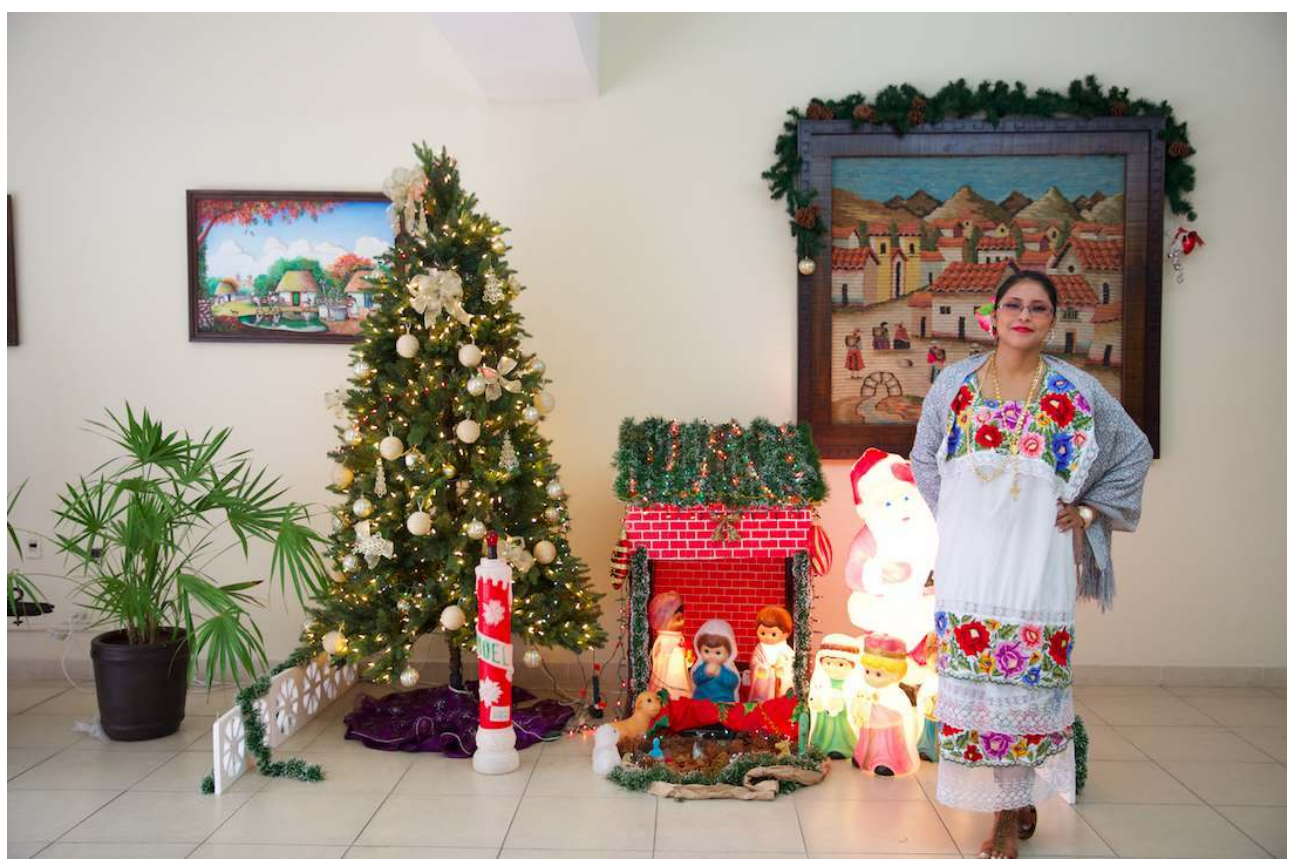

Mexico, Mérida: a woman with native Yucatec traditional clothes in front of Christmas nativity scene, lobby of a downtown hotel. 23 December 2014.

Photo by Laetitia Gessler 


\section{On religious vitality in Mexico}

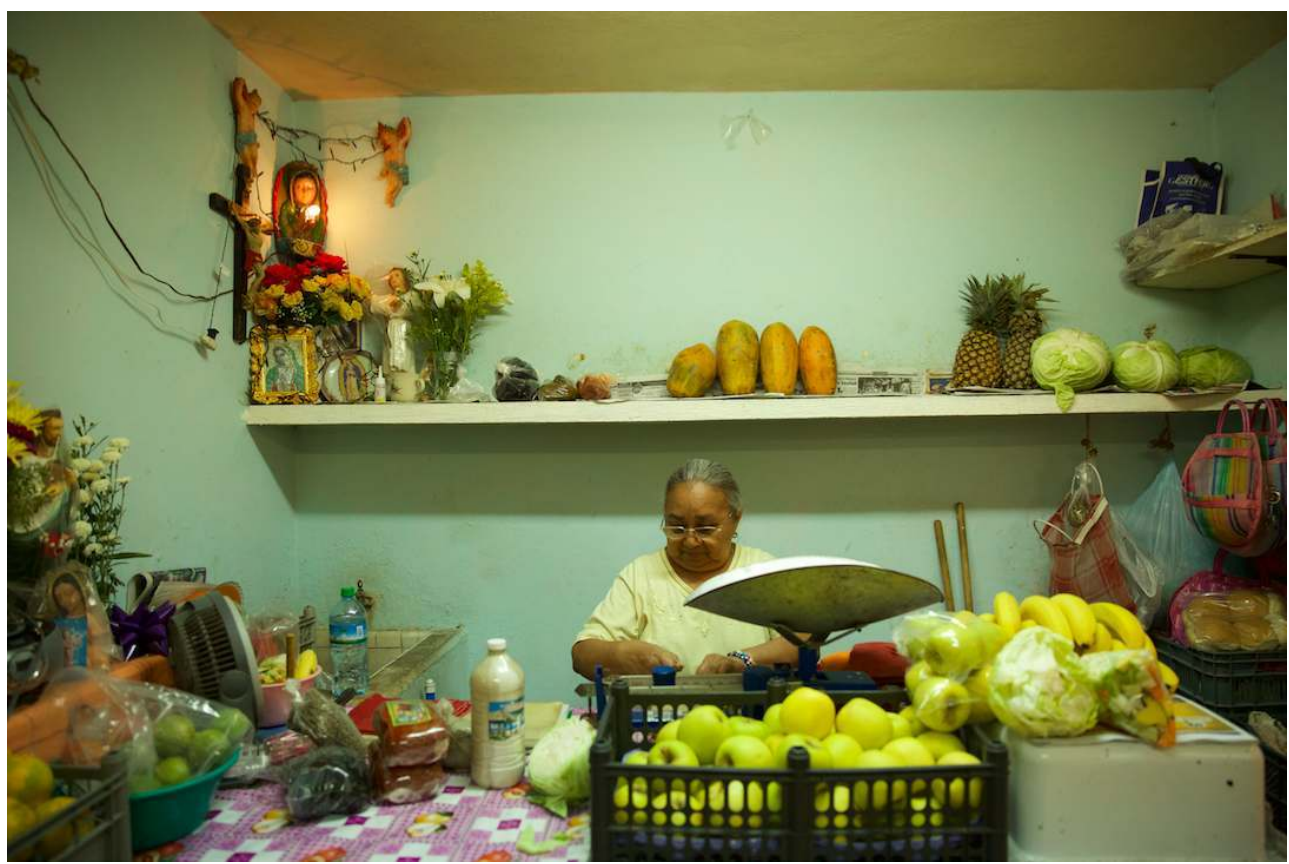

Mexico: Market in Mérida, small fruits and vegetables shop, with a syncretic altar. 15 December 2014 Photo by Laetitia Gessler

\section{On ceremonial altar}

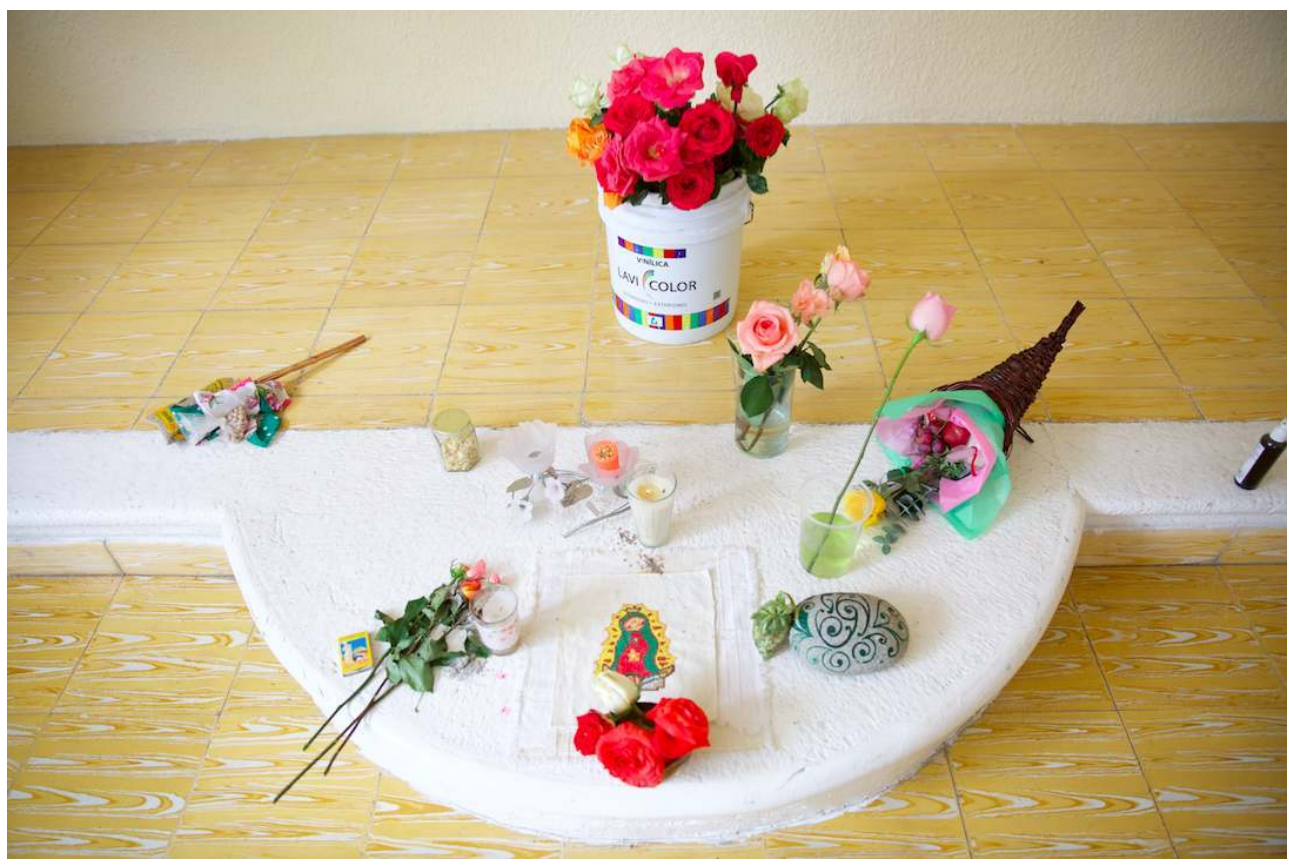

Mexico, Mérida: Altar for the "Ceremony of blessing", with healing roses, a cornucopia (Horn of Plenty), the figure of the Virgin of Guadalupe, white candles. 11 January 2015.

Photo by Laetitia Gessler 


\section{Ethnographic Commentary of the Images}

During our collaboration, we had one slight disagreement when writing the captions for the photographs. We had to define the status of our respective disciplines: did photography serve anthropological discourse or act as a support, or was it the other way around? The time had come to open up a dialogue and adopt a concept flexible enough to integrate any type of communicative context (academic and artistic). More specifically, we took a critical look at the style of writing and the descriptive strategies: how should we account for an ambiance, a portrait, a ritual? How should we integrate the participants' life stories in the comments and in the contextual or interpretive elements? How should we integrate both the anthropological approach and the photographer's gaze? Did we need to adopt a style that was poetic or literary, descriptive and factual, or meta-descriptive? How were we to combine these different levels of discourse and different lexical registers?

The anthropological literature on the use of photography emphasizes that the scientific use of the image is not in itself sufficient. It must be accompanied by a caption or a contextualizing note intended to fill the gaps related to non-verbal content, such as the secrets shared during biographical interviews or information on space and time (Conord 2007:15). The reinterpretation of the image through descriptive commentary is also a way of reinforcing the scientific legitimacy of the collaboration, as well as the documentary value of the image. Anthropologist Albert Piette's article (2007) mentioned previously, highlights three types of ethnographic writing based on the work of Van Maanen (1988). First, the "realist" tale consists of describing a social situation in direct relation to the representation of the image. Second, the "confessional" tale is where the ethnographer personalizes the description associated with her experience. This tale is characterized by a lack of neutrality. The commentary highlights her position, feelings and personal engagement while emphasizing reflexivity. Third, the "impressionist" tale, which may sometimes be literary, sheds light on a scene or sequence of events, that is, it develops one moment of observation in detail (Piette 2007: 27). In our project, we used all three descriptive forms, alternating between detailed and generalist approaches. For the photographic portraits, we privileged tales with commentary in the form of interview excerpts or dialogue between the ethnologist and locals in the field. This way of writing, emphasizing actors' subjectivity, also served to give value to and restore their stories and testimonies. As a case in point, the photographic images below, taken during the project, are accompanied by captions in the form of dialogues. 


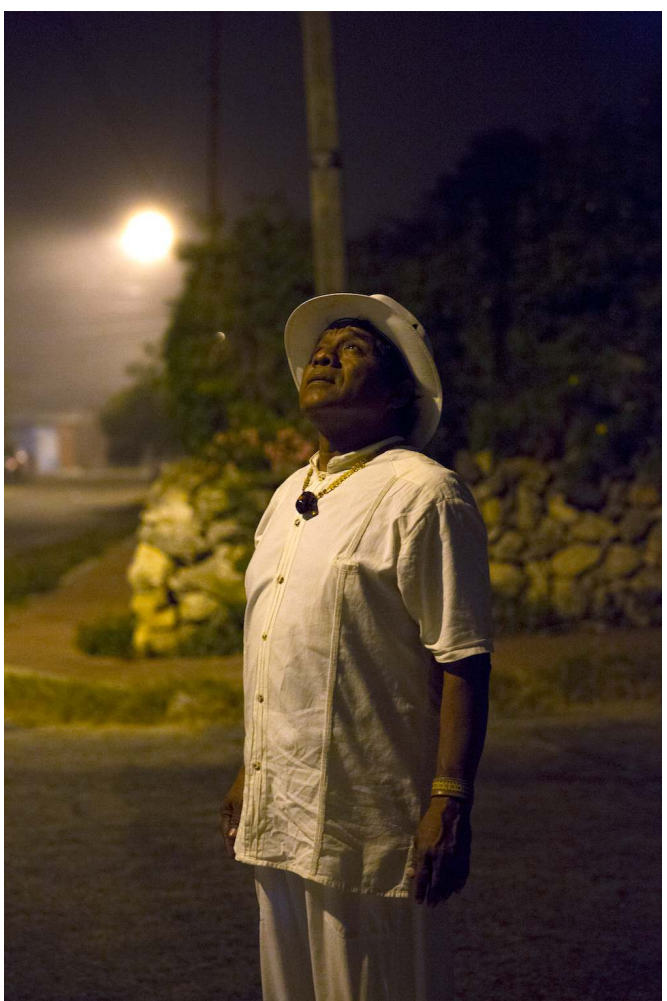

Mexico, Mérida: Yax Kin, before the winter solstice Ceremony. 21 December 2014.

Photo by Laetitia Gessler

Tiburcio Kan May, also known as Yax Kin, a Maya spiritual guide of Yucatán origin, lives on the outskirts of Mérida with his wife and children. Yax Kin always relates to his community of origin, recalls his ancestry and his initiation journey. He enjoys a certain authority in the region. This morning, at $5 \mathrm{am}$, we were waiting in front of the ritual space dedicated to winter solstice, a Maya rite to the four directions and four elements.

Manéli: What were you telling me about the stick?

Yax Kin: Oh, the power stick? They've got some kind of force, some kind of power, these things.

Manéli: Do you have these things?

Yax Kin: No, no, not yet. You know it doesn't happen to you overnight. [Pause]. It's a long process.

Manéli: Oh, yes.

Yax Kin: That's why it's different [talking about the Maya Solar Tradition]. You can know things, you can do a lot of things, but for the Elders...You've got to feel it, and they've got to see if you're ready for the power stick. It's not easy to get a power stick. You've got to be a leader.

Manéli: It's like a path...

Yax Kin: That's right, it's a path. It's like...We [Mayas] start when we're really young, with our grandparents behind us, up in the hills, in nature, in the corn field, in our work, by doing all this. And when they leave, well, we follow after them, but to get a power stick is not easy. [...]. I could make my own, you take a normal stick of wood, you decorate it, make it pretty, just like a power stick. But I don't know... It's only a joke! The best, most real power sticks you can get, is when your grandfather gives you one. 


\section{Master moo}

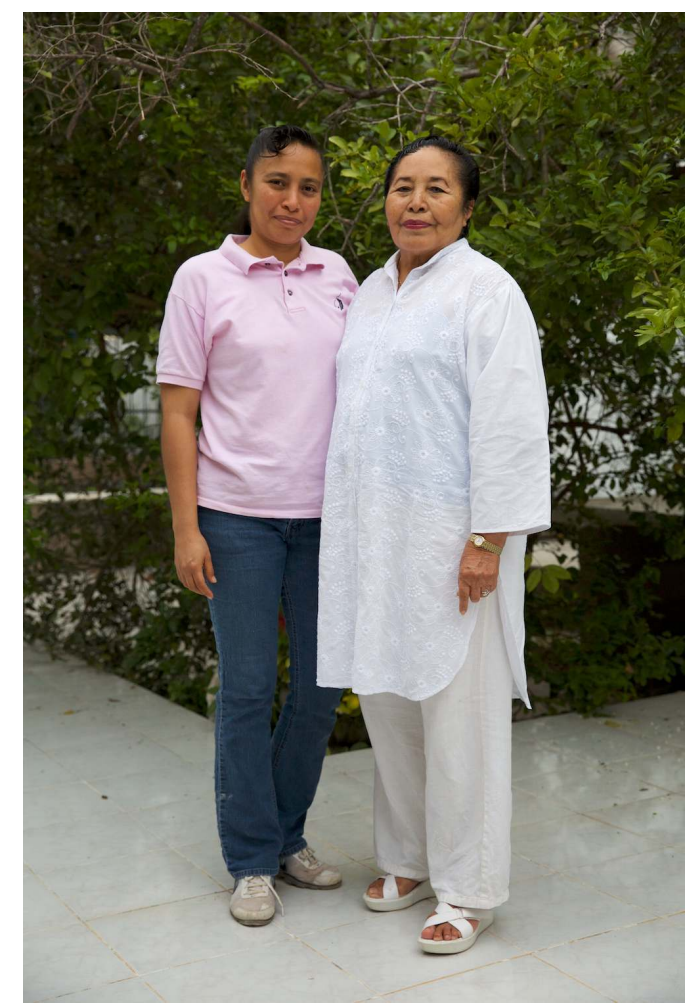

Mexico, Mérida: Master Moo and her daughter in their "regeneration Centre". 16 January 2015.

Photo by Laetitia Gessler

Master Moo and her daughter Selmy run this Centre for people with cancer. The products are grown according to the principles of Maya numerology and biodynamic agriculture.

Moo: Have you fallen in love with a Mexican?

Manéli: With a Mexican man? No, no, no [laughs].

Moo: [laughs]. That's good... That's good you haven't.

Manéli: For the time being, no.

Moo: No, no, no...

Manéli: It's better not to?

Moo: No, they're very macho.

Manéli: Ah, yes...

Moo: They are very macho. You need to give it to them below the belt.

Selmy: Okay, but the Iranians are also...

Moo: Oh, yes, they're worse. But I don't understand it because... [pause]. The world, in reality, belongs to women. Why do they let themselves be manipulated? If you bring a son into the world, you educate him. So why do you allow for this? Women are the ones who hold the world, the entire planet in their hands. [...]. Women are responsible for the way that men are. Women are responsible [pause] - you don't think the same way.

Manéli: Mmm, no, yes, I don't know. Aren't they both responsible? Isn't the responsibility shared?

Moo: No.

Selmy: Who educates us? Who teaches us our first lessons? Who do we beat?

Moo: Look, during the nine months you're carrying your child in your stomach, from that time, you start to educate him. You can talk to him, because he doesn't understand the words, but he feels the vibrations. [Laughs]. Later, you teach him to walk, you teach him to talk, and you teach him to have feelings. 'Mommy loves you 
and you love Mommy', isn't that so? [...]. Men are the way women would like them to be. If you educate them to be macho, they will grow up to be macho.

\section{Conclusion}

This article aimed to describe the history of a collaboration between ethnography and photography in a neo-Maya field in Mexico. Through our collaborative approach, we seek to strengthen the place of the photographic image in the social sciences. As Sylvain Maresca points out in his article on the relationship between photographers and ethnologists, collaborations are rare even though they would make it possible to broaden the tools of inquiry and data valorisation and promote reflection on the methods of knowledge production (Maresca 2007: 62). Even though collaboration can sometimes be difficult because of the divergence in objectives and the requirements placed on the approach, it makes sense insofar as documentary photographers and ethnologists are "specialists in forming relationships with others" (Maresca 2007: 62). In our project, bringing the two methods together was a means of initiating fruitful exchanges about methods and reconciling the relationship between form and substance. In sum, we have seen that this work allowed us to create images as a way of illustrating an anthropological discourse within a particular field of research. By creating images, we aimed for an indepth, more detailed and analytical understanding of the field. In addition to its illustrative dimension, the photographic work served as a tool for comparing different intranational ceremonial contexts from the perspective of a multi-sited ethnophotography. Photographs served an expressive function and became a visual field diary useful for scientific analysis. The work of classification, coding and categorization reinforced the expressive and analytical function of the images. In this sense, use of the photographic medium enabled us to contribute more materials, or at least previously inaccessible materials, through a single synchronic observation. Finally, the collaborative work helped us gain access to the field and build relationships of trust with the actors.

\section{BIBLIOGRAPHY}

\section{Books and articles}

Argyriadis, Kali and Renée De La Torre. 2012. Présentation générale et méthodologie: les défis de la mobilité. In Religions transnationales des Suds. Afrique, Europe. Amériques. Kali Argyriadis, Stefania Capone, Renée De La Torre and André André, eds. Pp. 13-25. Paris: Harmattan.

Becker, Howard. 1981. Exploring Society Photographically. Northwestern University: Mary and Leigh Block Gallery.

Campbell, Colin. 1972. The Cult, the Cultic Milieu and Secularization. A Sociological Year-book of Religion in Britain, 5:119-136. 
Capone, Stefania. 2004. A propos des notions de globalisation et de transnationalisation. Civilisations 51. http://civilisations.revues.org/634. (accessed 11 January 2019)

Collier, John and Malcolm Collier. 1986. Visual Anthropology. Photography as a Research Method. University of New Mexico Press: Albuquerque.

Conord, Sylvaine. 2007. Usage et fonctions de la photographie. In Ethnologie française Arrêt sur images: Photographie et anthropologie. Sylvaine Conord, ed. Pp. 11-22. 1 (37). Paris: Presses Universitaires de France.

Dias, Nélia. 1994. Photographier et mesurer: les portraits anthropologiques. Romantisme 84: 37-49.

De La Peña, Francisco. 1999. Le mouvement de la mexicanité ou l'invention de l'autre néotradition: millénarisme et imaginaire indigène. Doctoral research. Ethnology. Paris: EHESS, superviser Marc Augé.

De La Peña, Francisco. 2001. Milenarismo, nativismo y neotradicionalismo en el México actual. Ciencias Sociales y Religión. 3(3): 95-113.

De La Torre, Renée, ed. 2012. El Don de la Ubicuidad: Rituales étnicos multisituados. México D.F.: Centro de Investigaciones y Estudios Superiores en Antropología Social (CIESAS).

De La Torre, Renée, Cristina Gutiérrez Zúñiga and Nahayeilli Juarez Huet, eds. 2013. Variacones y apropiaciones latinoamericanas del New Age. México, D.F.: Centro de Investigaciones y Estudios Superiores en Antropología Social (CIESAS).

De La Torre, Renée and Cristina Gutiérrez Zuñiga. 2013. Introdución. In Variacones y apropiaciones latinoamericanas del New Age. Renée De La Torre, Cristina Gutierrez Zuñiga and Nahayeilli Juarez Huet, eds. Pp. 13-27. México, D.F.: Centro de Investigaciones y Estudios Superiores en Antropología Social (CIESAS).

Edwards, Elizabeth. 1992. Introduction. In Anthropology and Photography 1860-1920. Elisabeth Edward, ed. Pp. 3-17. New Haven and London: Yale University Press.

Frigerio, Alejandro. 2013. Lógicas y límites de la apropiación new age donde se detiene el sincretismo. In Variacones y apropiaciones latinoamericanas del New Age. Renée De La Torre, Cristina Gutiérrez Zúñiga and Nahayeilli Juarez Huet, eds. Pp. 47-70. México D.F.: Centro de Investigaciones y Estudios Superiores en Antropología Social (CIESAS).

Galinier, Jacques. 2011. Le montage des autochtonies. Translocalisation de la Terre Mère dans le New Age amérindien. Topique, 114 (1): 23-34.

Galinier, Jacques and Molinié Antoinette. 2006. Les néo-indiens. Une religion du IIIe millénaire. Paris: Odile Jacob.

Game, Valérie. 2007. Quelles autorisations pour l'utilisation d'une photographie. In Ethnologie française Arrêt sur images: Photographie et anthropologie. Sylvaine Conord, ed. Pp. 87-88. 1 (37). Paris: Presses Universitaires de France.

Glaser, Barney and Anselm Strauss. [1967] 2010. La découverte de la théorie ancrée. Stratégies pour la recherche qualitative. Paris: Armand Colin.

Maurines, Béatrice and Angel Sanhueza. 2004. Renouvellement du terrain par la photographie: La coopération d'une ethnologue et d'un photographe. Bulletin de Méthodologie Sociologique, January, Paris, n81: 33-47.

Marcus, George E. 1995. Ethnography in/of the World System: The Emergence of Multi-Sited Ethnography. Annual Review of Anthropology 24: 95-117. 
Maresca, Sylvain. 2007. Photographes et ethnologues. In Ethnologie française Arrêt sur images: Photographie et anthropologie. Sylvaine Conord, ed. Pp: 61-67. 1 (37). Paris: Presses Universitaires de France.

Mead, Margaret and Gregory Bateson. 1942. Balinese Character: A Photographic Analysis. New York: New York Academy of Sciences.

Monsutti, Alessandro. 2007. Le baiser de l'ethnographe: entre don de soi et usage de l'autre sur le terrain. In Entre ordre et subversion: logiques plurielles, alternatives, écarts, paradoxes. Suzanne Chappaz- Wirthner, Alessandro Monsutti and Olivier Schinz, eds. Pp. 23-35. Genève and Paris: IHEID ; Karthala.

Piette, Albert. 2007. Fondements épistémologiques de la photographie. In Ethnologie française Arrêt sur images: Photographie et anthropologie. Sylvaine Conord, ed. Pp. 61-67. 1 (37). Paris: Presses Universitaires de France.

Pinney, Christopher. 2011. Photography and Anthropology. London: Reaktion Books.

Sotelo, Santos and Laura Elena. 2002. Los dioses: Energía en el espacio y en el tiempo. In Religión maya. Camino Mercedes De la Garza and Martha Illia Nájera Coronado, eds. Pp. 83-114. Madrid: Editorial Trotta.

Strauss, Anselm and Juliet Corbin. 2004. Les fondements de la recherche qualitative. Techniques et procédures de développement de la théorie enracinée. Fribourg: Editions Saint-Paul.

Van Maanen, John. (1988). 2011. Tales of the Field. On Writing Ethnography. Second edition. Chicago: Chicago Guides to Writing Editing and Publishing.

\section{Website}

Venerable Abuela Nah Kin http://www.venerableabuela.com/2015/02/kinich-ahau-sabiduriasolar-capitulo-i_6.html. (accessed 10 June 2015).

\section{NOTES}

1. I would like to thank Kelly Akerman for the English revision.

2. The research features qualitative case studies conducted in different national contexts. Six field studies were carried out as part of a multi-situated ethnography spanning Mexico, Guatemala, Switzerland and Germany, using methods such as narrative interviews, direct participant observations, cyber-ethnography, and ethno-photography.

3. This expression is synonymous here with "Maya New Age". The work of Renée de La Torre, Cristina Gutiérrez Zúñiga and Nahayeilli Juárez Het (2013) have shown that the spread of the New Age in Latin America at the end of the 20th centurybrought about a wave of contextual appropriation and resemantization among local ethnic groups who were seeking to revitalize their traditions. Conversely, New Agers in search of tradition, authenticity and Indigenousness have also drawn on pre-Hispanic traditions and given them new meanings. The result of this encounter between the local and the global is indicated by the prefix "neo" (e.g., neo-tradition, neo-religion, neo-Mexicanity, neo-Indian, neo-ethnic) in the sense of requalifying the traditional (De La Torre and Gutiérrez Zúñiga, 2013: 18).

4. My multi-sited fieldwork took place between 2012 and 2015 as part of my doctoral dissertation. 5. By New Age Maya, we mean present-day - transnationalized - currents, where pre-Hispanic Maya traditions are revitalized. These currents offer a reinterpretation of pre-Hispanic principles and rites (especially the Maya calendars) through a New Age (holistic and millenarian) interpretive framework. 
6. The Solar Maya Tradition is an organisation whose seat is in Merida, led by the "Venerable Mother Nah Kin", a Mexican Mixed-race woman, who followed spiritual masters from various traditions. The leaders, called "Ahaukanes", have given themselves the mission to "save the spirituality of pre-Hispanic Maya civilisations", which they also call "Solar Mayas" or "Cosmic Mayas from the Golden Age". The reading of Mayanity is New Age, since a central place is given to millenarianism (waiting for the coming of a "new paradigm"), "personal transformation" and the discursive opposition to institutional religious models.

7. See the image on the official website of the movement: http:// www.venerableabuela.com/2015/02/kinich-ahau-sabiduria-solar-capitulo-i_6.html, accessed on 10 June 2015.

8. The scholarly literature suggests different meanings of the term "New Age". Strictly speaking, it designates a historic movement from California characterized by the expectation of a new age, the "Age of Aquarius" (Van Hoove 1999). In a broader sense, and in the wake of counter-culture currents, the New Age is a generic expression encompassing a wide variety of representation, with shades of personal development, Indian wisdom, Western esotericism and Amerindianism (Mayer 2013). In this text, we take the position to use the expression "New Age" as a "meaning matrix", a frame of "holistic interpretation" based on a specific millenarian world-view, involving the vision of a new era forthcoming down here (see De La Torre and Gutiérrez Zuñiga 2013).

9. By "neo-Indian" we refer to what American ethnologists Jacques Galinier and Antoinette Molinié have observed in Mexico and Peru in the nineties: "New forms of Indianity's" becoming public during the celebration of the Fifth Centenary of colonisation (Galinier and Molinié 2006: 27). This new phenomenon would build itself according to the mirror that westerners offer, mainly New Agers. Neo-Indianity would establish itself by evolving between the "particularism inside the local" and a "world-wide message" of "cosmic energy" diffusion (Galinier and Molinié 2006: 9; 187). Its leaders are generally non-native and consider themselves as "purest" than the Indians of rural communities (Galinier and Molinié 2006: 17).

10. Personal translation from Spanish to English.

11. For Laetitia Gessler, for example, the aesthetic dimension of the images reinforced the stories of the people in the field to the point of highlighting certain social logics.

12. Personal translation from French to English.

13. Personal translation from French to English.

14. This is true to the point where use of this medium in the social sciences is sometimes criticized for being "too subjective" and "too aesthetic" (Conord 2007).

15. The original text was written in French.

16. The Council is embodied by the Association Kuch kaab Yéetel J-Men Maaya'Ob, in Spanish: Consejo de Ancianos y Sacerdotes Mayas, whose executive committee sits in Mérida. The association was created in the 2000s. It aims to coordinate meetings of continental native representatives, working for the "development and promotion of Maya Culture values". It also celebrates local ceremonies and fight against "any form of cultural discrimination and economic marginalization of Maya people". The sources result from the official document of the Council, received in Mérida during their General Assembly, on 21 December 2014.

17. No public dissemination of information considered too intimate by the participants - an element of which we were generally made aware after the biographical interviews.

18. On the gift and counter-gift as means for creating balanced and reciprocal relationships in the field, refer to Monsutti (2007). 


\section{ABSTRACTS}

This paper discusses the collaboration between a photographer and an ethnologist during fieldwork on neo-Maya transnational movements. We will discuss some ethical and methodological issues linked to the collaboration, such as processing the photographic images, ethnography and photography as complementary tools, locating the photographic medium in the field of visual anthropology, the issue of the right to one's image, and the objectives of such collaboration. Finally, we will discuss the dimension of ethnographic commentary of the images and conclude with some propositions.

Cet article traite de la collaboration entre photographe et ethnologue sur un terrain particulier, les mouvements néo-mayas transnationaux. Seront discutées des questions éthiques et méthodologiques autour de la collaboration, telles que le traitement des images photographiques, l'ethnographie et la photographie comme des outils complémentaires, la place du medium photographique dans le champ de l'anthropologie visuelle, le droit à l'image et les objectifs de la collaboration. Enfin, nous aborderons la dimension des commentaires ethnographiques des images et conclurons avec quelques propositions.

Este artículo discute la colaboración entre fotógrafo y etnólogo durante un trabajo de campo sobre los movimientos neomayas transnacionales. Analiza cuestiones éticas y metodológicas alrededor de la colaboración, tales como el tratamiento de las imágenes fotográficas, la etnografía y la fotografía como herramientas complementarias, la situación del médium fotográfico en el campo de la antropológica visual, el derecho a la imagen y los objetivos de la colaboración. Finamente, abordaremos la dimensión de los comentarios etnográficos a las imágenes y concluiremos con algunas propuestas.

\section{INDEX}

Mots-clés: photographie, spiritualités New Age, méthodologie, commentaires ethnographiques, anthropologie visuelle.

Keywords: photography, New Age spiritualities, methodology, ethnographic legends, visual anthropology.

Palabras claves: fotografía, espiritualidades de la Nueva Era, metodología, leyendas etnográficas, antropología visual.

\section{AUTHOR}

\section{MANÉLI FARAHMAND}

University of Lausanne (Switzerland), University of Ottawa (Canada) maneli.farahmand@unil.ch

Manéli Farahmand is a PhD student at the Institute of Social Sciences of Contemporary Religion, University of Lausanne, and the Department of Classics and Religious Studies, University of 
Ottawa. Her ethnographic research focuses on the emergence of a transnational neo-Mayanism since the "2012 Phenomenon". 